Vol. 2, No. 2, 2015

\author{
H. M. Zakharchyn \\ Doctor of Economics, Professor,
}

N. P. Lyubomudrova

$\mathrm{PhD}$ of Economic Sciences,

Lviv Polytechnic National University

\title{
MOTIVATING PERSONNEL CREATIVE POTENTIAL
}

\begin{abstract}
This article discusses the motivational aspects of personnel creative potential in today's conditions, which is a driving force for innovation. Also the objective reasons that forced staff to develop creative potential of each company, in particular, the basic principles of formation of motivational policy for the development of creativity of staff are highlighted. The presented research shows the relationship between typology of staff work and the character of motivation, as well as determines the effectiveness of the enterprise staff creative potential motivation on the basis of various motivational tools.

The efficient processes of transformation will be successful only in case of the availability of creative potential of personnel able to produce innovative ideas, to support presence of the enterprise on the innovation market and to ensure its competitiveness through unconventional management solutions.

Creativity is a natural human characteristic, however, subject to certain circumstances; it is not always possible to utilize it as a driving power in innovative development of an enterprise. Because of the lack of proper motivational policy, creativity often remains just a personal condition, and there is only nominal development and use of its potential. Thus, a contradiction emerges between the objective need to implement the personal creative impulse and subjective obstacles to human development.
\end{abstract}

Key words: motivation, motivation policy, creative potential, creativity, innovativeness, stimulating.

Analysis of recent research and publications. In the scientific community creativity of personnel is traditionally considered as a part of the social capital $[2,15]$ and an important factor of innovative development of an enterprise $[6,8,11,14]$. In the context of combination of creativity and staff incentives, particular publications are considered noteworthy [1, 2, 7, 14]. Namely, Bashkus T.O. and Khyzhnyak M.O. explore staff creativity in relation to the values of organization, while describing the factors of creativity development. However, they review upto-date staff incentives fragmentarily, just listing them. Scientific literature $[3,4]$ contains confirmations of the complexity of the motivation problem and research of motivational behavior, which is both contradictory and dynamic. The combination of the motivational func- tion of management and development of intellectual potential of an enterprise, as well as creativity, are partially presented in author's monograph [4] and other publications [6, 7].

Despite wide presence of certain aspects of the problems outlined in the scientific community, there is yet no comprehensive study of the creative potential in the light of motivation of its development, taking into account current challenges.

Research objectives. The purpose of the article is to highlight the motivational aspects of creative potential of personnel under current conditions. To achieve this objective, the author uses such scientific methods as comparative analysis and synthesis, when elaborating the concept of "creative potential staff", analyzing scientific sources and studying academic views of the outlined problems, defining objective reasons which force enterprises to develop their staff creative potential.

Main statement. Creativity of each individual intensifies the innovation activities of the enterprise as a whole, and due to synergetic laws transforms into creative potential of personnel, which is capable of saturating the market with new ideas and increasing business activity of the company. This is true, and meets the requirements of the time, because innovations appear to be a competitive advantage, and creativity is a creative accomplishment of an individual, which affects the growth of the number of people who think in an unconventional way, and seek for self-actualization. Creative potential is seen as the person's ability to stay in the creative tone, capacity to realize his/her potential as a creative person in a professional environment, and gain business results from creativity. Regarding enterprises, the effectiveness of creative activity is mandatory, therefore the creative potential covers all stages of innovations and their implementation, i.e. achieving business results. The time lag is an important issue, concerning how fast the ideas are converted; 


\section{H. M. Zakharchyn, N. P. Lyubomudrova}

therefore, motivational levers have to be selected at each stage of the innovations life cycle.

Thus the following objective causes for developing the personnel creative potential at the enterprise need to be identified:

Firstly, it is an evolutionary requirement of time, which enhances innovation in all areas;

Secondly, it is progress, which essentially reflects the development of both the individual and the enterprise;

Thirdly, it is a new tool which increases the adaptive ability of enterprises and personnel;

Fourthly, it is a competitive advantage of a fundamentally different nature;

Fifthly, information and intellectual society is the result of creative activity, among all other factors, which accordingly stimulates creativity.

The information and intellectual society significantly changes the essense of work, adding creative nature to it. There appear new professions, which require creativity; new relationships between people and with factors of production; new organizational structures, management practices and more. Thus the creative process is no longer a separate episode but becomes widespread, while the use of modern information and computer technologies simplifies the implementation of innovative ideas and leads them to commercial effect.

So, the development of creativity cult is a managers' priority. They ought to effectively utilize the motivational mechanism, being mindful of the fact that motivation depends on the type of organizational culture, management style and managers' own views on leadership. For example, authoritarian management style does not stimulate the emergence of a creative leader. This type of management is bureaucratic in nature and involves strict observance of the rules, formalization of personnel's functions. If the distance of power is small as it usually is in the cultures of democratic type, such as market or innovative, then creative capacity of the manager increases. Attention is mostly focused on motivating ideas, imitativeness in the culture of achievements. In this type of culture motivation is not sporadic, but it is an effective policy of strengthening personnel within the organization.

The need to enhance the motivational policies regarding the development of creative potential is supported by the poor results of innovation activities, as the number of actively innovating enterprises constituted $16.8 \%$ of all enterprises in 2013; funding innovations in the industrial sector was $0.3 \%$ in 2013 , in comparison with $2,0 \%$ in 2012. The volume of innovative production is constantly reduced: $42,386,7$ million in 2011 and 35,891,6 million in 2013. The same situation is in the sphere of implementing new processes: 2510 in 2011 and 1576 in 2013, although in 2013 50,7 \% of enterprises implemented new technological processes, compared to $43,6 \%$ in 2012 [13, p. 300-302].

The basic principles of motivational policy formation for the development of staff creativity are identified as follows:

Firstly, the extension of the area of motivational development of the staff creative potential;

Secondly, the principle of incentives should be extended to cover the entire creative staff, not only management;

Thirdly, the value of motivators for activation of technical creativity of staff should increase;

Fourthly, the principles of flexibility, personalization, differentiation and productivity should be combined with the effectiveness of the innovation project;

Fifthly, the principle of consistency in the motivational mechanism should be adhered to, as even the slightest deviations from the declared principles of stimulation significantly reduce the authority and credibility of managers.

These principles of motivation have effect in different circumstances and conditions. It is important that personnel be aware of the interconnection between their fulfilling of duties and a system of rewards, then the stereotype of perception and understanding of behavior based on values of trust will function. It will affect the attitude to work, the responsibility for quality, and, ultimately, creative potential of each person.

Table 1 demonstrates the interdependence of types of work and the nature of motivation.

\section{The interdependence of types of work and nature of motivation}

\begin{tabular}{|l|l|}
\hline Types of managers' work & Predominant motivation \\
\hline $\begin{array}{l}\text { 1. Engineering } \\
\text { 2. Innovative and technological }\end{array}$ & $\begin{array}{l}\text { Combination of } \\
\text { collective and personal } \\
\text { reward personal reward }\end{array}$ \\
\hline $\begin{array}{l}\text { 3. Results (for example, produc- } \\
\text { tion) } \\
\text { 4. Innovative and experimental }\end{array}$ & $\begin{array}{l}\text { personal reward } \\
\text { personal reward }\end{array}$ \\
\hline $\begin{array}{l}\text { 5 Functional (marketing, human } \\
\text { resources, finances, supply) }\end{array}$ & $\begin{array}{l}\text { personal reward, collec- } \\
\text { tive reward }\end{array}$ \\
\hline 6. Creative and innovative & $\begin{array}{l}\text { Combination of collec- } \\
\text { tive and personal reward }\end{array}$ \\
\hline
\end{tabular}

Source: adaptation of [4] 


\section{Motivating personnel creative potential}

The information presented in Table 1 reflects the general trend of increased attention to personal approaches to character motivation. A personal reward is a desirable kind of incentive mainly for all kinds of work and usually takes the form of bonuses, though it may be intangible. It should be noted that the present practice of encouraging creativity through financial incentives no longer brings the desired effect, as more people are deeper engaged in the world of art, so motivation should come from the nature of human desire of self-improvement, development, intellectual and spiritual enrichment.

"Collective remuneration is the result of certain collective success of the business unit, or it is offered due to project implementation. Stimulating effective cooperation between departments is also collective, especially when it involves execution of an important innovation project or participation in solving integrated problems" $[4$, p. 112]

Development of motivational policy based on outlined approaches and principles provides high performance of the enterprise. Table 2 shows the influence of motivation tools of personnel creative potential on the activity of enterprise.

\section{Effectiveness of motivation of personnel creative potential}

Table 2

\begin{tabular}{|c|c|}
\hline Tools of motivation & $\begin{array}{c}\text { Results of motivation of } \\
\text { personnel creative potential }\end{array}$ \\
\hline $\begin{array}{c}\text { developing skills of per- } \\
\text { forming tasks with } \\
\text { optimal amount of } \\
\text { resources }\end{array}$ & $\begin{array}{c}\text { increasing business } \\
\text { activity in general, gro- } \\
\text { wing social and economic } \\
\text { performance indicators }\end{array}$ \\
\hline$-\begin{array}{l}\text { opportunity to combine } \\
\text { third unordinary object } \\
\text { with two common ones } \\
\text { (Centaurus idea) }\end{array}$ & $-\begin{array}{l}\text { improvement of technical } \\
\text { and technological } \\
\text { parameters of innovation } \\
\text { products or services }\end{array}$ \\
\hline $\begin{array}{l}\text { personification of } \\
\text { authorship for target } \\
\text { audience in long-term } \\
\text { period }\end{array}$ & $\begin{array}{l}\text { realization of needs, self- } \\
\text { actualization, self-identifi- } \\
\text { cation, acknowledgement, } \\
\text { strengthened self-motiva- } \\
\text { tion }\end{array}$ \\
\hline$-\begin{array}{l}\text { individual and emotio- } \\
\text { nal positioning in exter- } \\
\text { nal communication }\end{array}$ & $-\begin{array}{l}\text { efficiency through the fee- } \\
\text { ling of being included into } \\
\text { one family of personnel }\end{array}$ \\
\hline$-\begin{array}{l}\text { professional evaluation } \\
\text { by competent experts } \\
\text { and bodies (Certifica- } \\
\text { tion centers, scientific } \\
\text { and technical councils, } \\
\text { specialized academic } \\
\text { councils) }\end{array}$ & $-\begin{array}{l}\text { permanent improvement } \\
\text { of professional skills of } \\
\text { personnel, forming po- } \\
\text { sitive corporate image }\end{array}$ \\
\hline $\begin{array}{l}\text { formation of uniqueness } \\
\text { by creating innovations } \\
\text { (products, services, } \\
\text { methods, technologies) }\end{array}$ & $-\begin{array}{l}\text { creating new market } \\
\text { conditions and generating } \\
\text { new segments }\end{array}$ \\
\hline
\end{tabular}

Source: developed by the authors
Motivation is a universal mechanism of preparation for free activity, if an individual combines intelligence, creativity and results. Incentives are a subsystem of motivation which includes impulses leading to the respective activity. Thus, the objective of motivational policy is balance in motives and incentives within a single motivational space for all personnel united by the idea of quality, creative work.

\section{Conclusions and prospects for further} research. Successful innovation progress of national enterprises is merely dependent on their internal capacities. The creative potential of the staff reflects the state of internal resources and is an internal stimulator of innovation development, the key to the competitiveness of enterprises, a dynamic factor which accelerates the implementation of new experience in various areas of social and economic practice. In order to develop creative potential it is required to build adequate personnel motivation policy, which can be achieved by a combination of modern motives and incentives, increases self-esteem and develops personnel's need to work on improving the competitive attractiveness of the enterprise.

Further research should be directed to the indepth study of both theoretical and practical aspects, including the methodological use of psychological structure of creativity in the practice of management personnel; designing models that allow evaluating the motivation influence effectiveness on the development of personnel creative potential, methodical approaches to determining levels of creative potential and the factors influencing it.

\section{References}

1. Bashuk T. O. Stymulyuvannja ta rozvytok kreatyvnosti personalu / T. O. Bashuk, M. O. Khyzhnyak // Marketyng I rozvytok innovacij. - 2013. - № 1. P. 150-160.

2. Bukovynska M. P. Kreatyvnist personalu jak neobhidna jakist formuvannja socialnoho kapitalu / M. P. Bukovynska, O. L. Nechajev // Naukovi praci NUHT. - K. : NUHT. - 2013. - № 51. - P. 122-128.

3. Goncharov V. M. Upravlinnja motyvaciyeyu personalu na pererobnyh pidpryjemstvah $P K$ : monografiya / V. M. Goncharov, A. V. Cherkasov. Lugansk; Yantar, 2010. - 267 p.

4. Zakharchyn H. M. Motyvuvannja $i$ rozvytok personal : kulturologichnyj aspect: monografiya / H. M. Zakharchyn, N. P. Lyubomudrova, R. O. Vynnychuk. - Lviv : Vydavnyctvo Lvivskoji politekhniky, 2015. $-284 p$. 


\section{H. M. Zakharchyn, N. P. Lyubomudrova}

5. Kalinichenko Y. B. Kreatyvnist jak osnova menegzhmentu organizacij / Y. B. Kalinichenko, Y. I. Smirnova // Marketyng i menedzhment innovacij. 2011. - № 4. - P. 186-191.

6. Kolot A. Innovacijna pracya ta intelektualnyj kapital u systemi faktoriv formuvannja ekonomiky znan / A. Kolot // Ukrajina : aspekty praci. - 2007. № 4. - P. 4-12.

7. Kuzmin O. Kreatyvnyj menedzhment : navch. posibnyk/ O. Kuzmin, S. Knyaz, I. Lytvyn, D. Zinkevych. Lviv : Vydavnyctvo Lvivskoji politekhniky, 2010. $124 \mathrm{p}$.

8. Kuznyecova N. B. Kadry innovacijnogo typu: sutnist, znachennja ta osoblyvosti formuvannja $v$ umovah rozvytku innovacijnoji ekonomiky / N. B. Kuznyecova // Aktualni problemy ekonomiky. - 2009. - № 6 (96). P. 115-121.

9. Lipych L. G. Genezys rozvytku teorij motyvaciji praci / L. G. Lipych, L. S. Pustulha // Nauka j ekonomika. - 2010. - № 1. - P. 114-117.

10. Lyashko D. Y. Teoretychnyj ohlyad informacijnogo ta komunikatyvnogo seredovyshch funkcionuvannja pidpryjemstv / D. Y. Lyashko // Akademichnyj ohlyad / Academy Review. - 2008. - № 2. - P. 63-68.

11. Protsak K. V. Kreatyvnist personal jak vazhlyvyj chynnyk innovacijnogo rozvytku pidpryjemstva / K. V. Protsak, O. P. Prosovych // Visnyk Nacionalnogo Universytetu "Lvivska politekhnika”. - 2011. № 698. - P. 272-276.

12. Revutska N. V. Formuvannja koncepciji intelektualizaciji biznesu v suchasnij paradygmi upravlinnja / N. V. Revutska // Formuvannja rynkovoji ekonomiky : Zbirnyk nauk. Prac. - Spec. Vypusk : Ekonomika pidpryjemstva: teoriya I praktyka. - Ch. II. - K. : KNEU, 2008. - P. 543-548.

13. Statystychnyj shchorichnyk Ukrajiny za 2013 rik za redakcijeyu Okulenka O. G. I Derzhavna sluzhba statystyky ukrajiny, 2014. - P. 533.

14. Chernenko V. Innovacijna pracja ta motyvacijni osnovy jiji rozvytku / V. Chernenko // Ukrajina: aspekty praci. - 2007. - № 6. - P. 30-34.

15. Shumakova I. S. Kadrovyj potentsial ta yoho vplyv na efektyvnist diyalnosti orhanizacij / I. S. Shumakova // Vestnik NTU “KhPI”. - 2010. - № 22. - P. 12-20. 